PLAYING FOR KEEPS 
IMPROVISATION, COMMUNITY, AND SOCIAL PRACTICE

A series edited by Daniel Fischlin

Books in this series advocate musical improvisation as a crucial model for political, cultural, and ethical dialogue and action-for imagining and creating alternative ways of knowing and being in the world. The books are collaborations among performers, scholars, and activists from a wide range of disciplines. They study the creative risk-taking imbued with the sense of movement and momentum that makes improvisation an exciting, unpredictable, ubiquitous, and necessary endeavor. 
Daniel Fischlin

and

Eric Porter,

EDITORS

\section{PLAYING FOR KEEPS}

Improvisation in the Aftermath 
(C) 2020 Duke University Press

All rights reserved

Printed in the United States of America on acid-free paper $\infty$

Designed by Matthew Tauch

Typeset in Minion Pro by Westchester Book Services

Library of Congress Cataloging-in-Publication Data

Names: Fischlin, Daniel, editor. | Porter, Eric, [date] editor.

Title: Playing for keeps : improvisation in the aftermath /

Daniel Fischlin and Eric Porter, editors.

Description: Durham : Duke University Press, 2020. |

Series: Improvisation, community, and social practice |

Includes bibliographical references and index.

Identifiers: LCCN 2019027309 (print)

LCCN 2019027310 (ebook)

ISBN 9781478006800 (hardcover)

ISBN 9781478008149 (paperback)

ISBN 9781478009122 (ebook)

Subjects: LCSH: Improvisation (Music)—Political aspects. |

Improvisation (Music)-Social aspects.

Classification: LCC ML3916 .P58 2020 (print) |

LCC ML3916 (ebook) | DDC 781.3/6-dc23

LC record available at https://lccn.loc.gov/2019027309

LC ebook record available at https://lccn.loc.gov/2019027310

Cover art: Randy DuBurke, from the series CIVIL JAZZ!

Courtesy of the artist.

Duke University Press gratefully acknowledges the Social Sciences and Humanities Research Council of Canada for its support of the Improvisation, Community, and Social Practice (ICASP) project, at the University of Guelph, which provided funds toward the publication of this book. 
for our beloved partners, Martha Nandorfy and Catherine Ramírez 
This page intentionally left blank 